\title{
Some Considerations regarding the Use of the Game Theory in International Commercial Negotiations
}

Răzvan MURARIU ${ }^{1}$

Abstract

The complexity of contemporary economic life, the increase in the number of negotiation partners located in large and diversified geographic areas, the possibility of choosing from a larger number of trade protection measures, tightening competition, differences and limitations in their use, lead to considerable growth the importance of international dialogue, negotiation between stakeholders on the basis of negotiation.

A specific area of international negotiations is the negotiations within the International Trade Organization (WTO) on tariff and non-tariff protection measures on the agricultural commodity market. The article describes the way in which gambling theory can be used in such negotiations, starting with the intensification of commercial protectionism lately, presenting a model of negotiation between the three major players in world trade (US, EU and China).

Keywords: negotiations, game theory, trade protectionism, WTO

JEL classification: C70, C71, F13, F51.

DOI: $10.24818 /$ RMCI.2019.2.180

\section{Introduction}

The analogy between negotiation and a chess match has often been made, in which each player moves his pieces so that his favorable position leads him to victory, or even to the draw. Like a chess player, a good negotiator thinks a few moves in advance and wonders what might happen if he rejects a bid. The answer to this question depends on the objective data of the problem. What is very important is not only to win, but to ensure continuity of earnings, which requires a negotiating manner that will make the partner maintain relationships.

In the presentation of the negotiation from the perspective of game theory, its characteristic features, namely the mixed motivation that combines cooperative aspects and competitive aspects, namely a rising sum game and a zero-sum game, must be analyzed. It is therefore necessary to consider an exchange of values between the participants.

\footnotetext{
${ }^{1}$ ASE București, PhD Student, murariu@ avocatmurariurazvan.ro
} 


\section{Methodology}

We perceive WTO negotiations as a dynamic game, this being a game in which players' decisions are sequential, that is, they are successive in time and with incomplete information, in which at least one of the players does not know one or more of the winning functions of the other players, the rest of the elements (the number of other players and the strategies of each) are known.

In game theory, a Bayesian game is one in which information about the other player's characteristics is incomplete.

To define the perfect Bayesian equilibrium we start from the following assumptions:

Hypothesis 1: For each set of information, the moving player must have some assumptions about what has been played before. For a lot of non-unique information, an assumption will be a probability distribution over the nodes in the set of information (Guasco, Robinson, 2007).

Hypothesis 2: Given their assumptions, players' strategies must be sequentially rational (that is, for every set of information given, the player's strategy must be optimal given the assumptions he has).

So, assumptions 1 and 2 consist in the fact that players assume the way others play and given these assumptions, each player acts rationally, ie chooses those strategies that maximize their winnings.

Hypothesis 3: For a lot of information on the path of balance, assumptions are determined by the Bayes rule and the players' balance strategies. So the notion of perfect Bayesian equilibrium will not only include players' strategies but also the assumptions they make about strategies chosen by others (Albin, 2001).

In many cases, assumptions 1-3 are the very definition of the Bayesian Perfect Balance, but we will also impose a condition that will seek to eliminate strategies that are not credible.

Hypothesis 4: On a lot of information outside the equilibrium path, assumptions are determined by the Bayes rule and the players' balance strategies - if possible.

So we will call the Bayesian Perfect Balance a lot of strategies and assumptions that satisfy the Hypotheses 1-4.

\section{Results}

We consider the next incomplete information game. Each player is informed of the previous actions of the other players. Moreover, each player acts in turn, not simultaneous movements. The game is a "tree" type (tree - tree). Each node is associated with a player who moves by choosing the next node. Lines joining nodes refer to the player's actions. The game starts at the initial node, the "tree root" and ends at the last node that determines the outcome of the game (Lewicki, Saunders, Barry, 2006). 
First, a player chooses between three actions: S (support for agriculture), B (use of barriers), and R (give up) and the probability is $\mathrm{p}$. If a player chooses $\mathrm{R}$ then the game ends without a player movement 2 . If a player chooses either $\mathrm{S}$ or $\mathrm{B}$, then player 2 learns that $\mathrm{R}$ has not been chosen (but not $\mathrm{S}$ or B was chosen) and then chooses between two actions S "and R" after which the game ends (Gibbons, 1996).

Using the normal form representation of this game we find that there are two pure-equilibrium Nash - (S, S ") and (R, R") strategies. So in the game, both (S, S ") and $(R, R ")$ are perfect Nash balances. However, it can be seen that (R, R ") clearly depends on an unreasonable threat: if the player 2 makes a choice then the choice $S$ " takes precedence over the choice of R "so that player 1 should not choose R, but R".

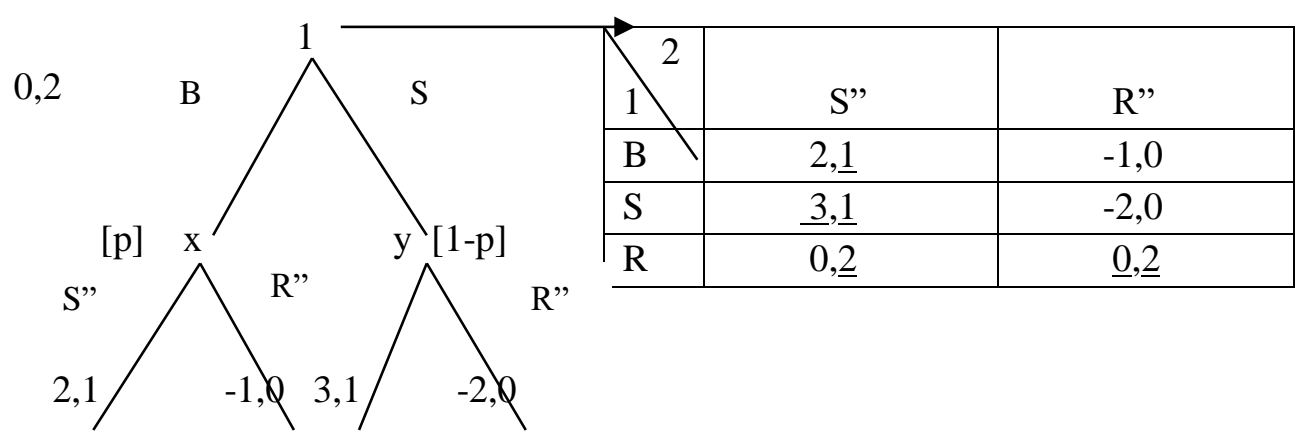

Figure 1. Negotiations as imperfect games

Source: Auror's calculations

The agricultural stagnation in the WTO negotiations is mainly due to the differences in support given to farmers in terms of the use of subsidies.

In the field of subsidies, the subject was the first time in the Tokyo Round, however, negotiations have intensified over the years to come.

Commitments made by member countries in the Uruguay Round by signing the Agriculture Agreement focused on the following areas related to subsidies:

- Internal support: waiver of subsidies or other types of programs guaranteeing incomes or prices for agricultural products;

- Export subsidies: The reduction in the amount of subsidies or the volume of subsidized exports in the trade in agricultural products was envisaged.

Specifically, the commitments were:

- progressively reducing domestic support for agriculture, with an average of $20 \%$ in industrialized countries and $13.3 \%$ for developing countries over a six-year period for developed countries and ten years for developing countries ;

- the gradual reduction in the industrialized countries of $36 \%$ of the amount of export subsidies for agricultural products and $21 \%$ of the quantities of subsidized exports in a staggered six-year period; for developing countries, export subsidies will be reduced by $24 \%$ for 
agricultural products and by $14 \%$ of subsidized export quantities over a ten-year period.

Also, the commitments made in this round provided for strengthening and strengthening the rules of action against unfair competition practices in international trade by limiting the use of export subsidies and clearer clarification of how to defend against such practices by introducing countervailing measures. Totodată, problema accesului pe piaţa a fost frecvent abordată în cadrul discuţiilor privind liberalizarea comerţului (Spoelstra, Piennar, 2008). Members' positions on agriculture and market access are generally given by the following: (i) supporting agriculture through subsidies and price support; and (ii) the use of barriers to entry into the foreign market.

We note the attitudes to agriculture issues (1) and (2) as follows:

\section{- A (to support agriculture) and A* (against support) \\ - $B$ (to impose barriers) and $B *$ (against barriers)}

Attitudes towards these issues call for the definition of four possible strategies: $\mathrm{AB}, \mathrm{AB} * \mathrm{~A} * \mathrm{~B}$ and $\mathrm{A} * \mathrm{~B} *$. Players can order these strategies, starting from the most favorable to the least favorable, taking into account the primary and secondary goals. Regarding the primary goal, the distinction between the most favorable strategies for a player is made in terms of results, and for the secondary objectives is the distinction between the two most favorable strategies, on the one hand, and the most unfavorable two strategies, on the one hand other side (Morgan, 1998). Thus, if (1) is A* and (2) is B *, the player would hierarchize strategies, from the most favorable to the worst, as follows: $(A * B *, A * B, A B *, A B)$.

Starting from the discussions in the WTO Round, the above ordering of the strategies corresponds to the position supported by the US. Therefore, given the primary and secondary objectives and the preferences involved, the order of strategies is as follows:
SUA:
(1) $\mathbf{A} *$ şi
(2) $\left\lceil\mathbf{B}^{*}\left\lceil\left(\mathbf{A}^{*} \mathbf{B}^{*}, \mathbf{A}^{*} \mathbf{B}, \mathbf{A B}^{*}, \mathbf{A B}\right)\left\langle\left(\mathbf{A}^{*}, \mathbf{B}^{*}\right)\right.\right.\right.$
UE:
(1) $\mathbf{A}$ şi
(2) $\left\lceil B^{*}\left\lceil\left(A^{*}, \mathbf{A B}, A^{*} \mathbf{B}^{*}, A^{*} B\right)<\left(\mathbf{A B}^{*}\right)\right.\right.$
China:
(1) $\mathbf{A}^{*}$ şi
(2) $\left\lceil\mathbf{B}\left\lceil\left(\mathbf{A}^{*} \mathbf{B}, \mathbf{A}^{*} \mathbf{B}^{*}, \mathbf{A B}, \mathbf{A B}^{*}\right)\left\langle\left(\mathbf{A}^{*} \mathbf{B}\right)\right.\right.\right.$

By comparing, for each pair of platforms that is socially preferred (by a majority of two out of three players), an order of social preferences is obtained as in the figure below: 


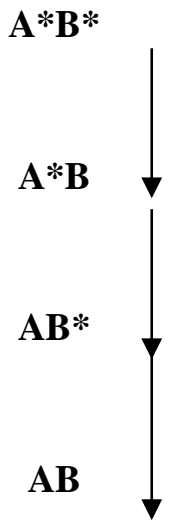

Figure 2. Social hierarchy of majority preference for strategies

Source: elaborated by the author

Note: The arrows starting from a strategy above to a strategy below show that the first is socially preferred (by a two-thirds majority of players) of the latter.

Two of the three players, indicated by the three arrows starting from $\mathrm{A} * \mathrm{~B}$ *, prefer the strategy mentioned above for each of the other three strategies. The fact that these other three strategies can also be ordered so that the flow of social preferences "descends" from $\mathbf{A}^{*} \mathbf{B}^{*} \Leftarrow \mathbf{A} * \mathbf{B} \Leftarrow \mathbf{A} \mathbf{B}^{*} \Leftarrow \mathbf{A B}$ establishes the existence of a "social hierarchy" of strategies. If each player has the right to veto the choice of a strategy, the fact that there is a social hierarchy based on the majority of preferences does not mean that a social consensus will develop about the location of the $\mathrm{A} * \mathrm{~B} *$ strategy at the top of the hierarchy. It is possible to reject each strategy by exercising the right of veto by the player who prefers another. Therefore, if general consensus is required, the likelihood of it being obtained is minimal (Poundstone, 1992).

Before applying the Negotiation Model to the preferences of each player, some clarification is required as to where the stalemate, I noted, is in the order of player preferences. We assume that the EU strongly supports (1), insisting on strategy A, ie support for agriculture, thus placing I in the third position. We believe that the US places the deadlock I in the fourth position: they will not give up the primary and the secondary goals. Then the only way to reach consensus is to place China in the fifth position. Supporting various alternatives leads to:

SUA:

$\left(\mathrm{A}^{*} \mathrm{~B}^{*}, \mathrm{~A}^{*} \mathrm{~B}, \mathrm{AB}^{*}, \mathrm{I} \xi \mathrm{AB}\right)$

UE:

$\left(\mathrm{AB}^{*}, \mathrm{AB}, \mathrm{I} \xi \mathrm{A}^{*} \mathrm{~B}^{*}, \mathrm{~A}^{*} \mathrm{~B}\right)$

China:

$\left(\mathrm{A} * \mathrm{~B}, \mathrm{~A}^{*} \mathrm{~B} *, \mathrm{AB}, \mathrm{AB}^{*}, \mathrm{I}\right)$

When players no longer support the strategies indicated by the vertical bars, unanimous $\mathrm{AB} *$ support is obtained. 
$\mathrm{A} * \mathrm{~B} *$ and $\mathrm{A} * \mathrm{~B}$ are in front of the $\mathrm{AB} *$ strategy within the hierarchy. The first strategies will be withdrawn when I is hierarchical due to the hypothetical intransigence of the EU. The hypothetical, to some extent, diminished intransigence of the US favors the $\mathrm{AB} *$ strategy in the face of the $\mathrm{A} * \mathrm{~B} *$ strategy. The situation will reverse if China places I in the fourth position and the US places it fifth. In this way, placing a player in a more advanced position determines the choice of a more favorable strategy for the player, even if the platform falls down in the social hierarchy, which is based on the majority rule (Fudenberg, Tirole, 1992).

The positioning of I by the last two players may not match the hypothesis from which he started. The hypothetical preferences of the players (for I or for the other strategies) and the unanimity rule do not capture all the possibilities of concluding the game played within the rounds of negotiations (Ury, 1994). Other rules, other preferences, or even other players may be included in the analysis if they believe they can provide a more realistic picture of the bargaining game in international trade (Kennedy, 2007).

Due to the crucial importance within the WTO, the issue of agriculture becomes the primary objective for all players. There is a possibility that players' positions on the market entry issue and the regional pact over the world will become more important in the coming period. The failure of rounds can lead to trade agreements on continental blocks (America, Europe and Asia), which some analysts are watching with concern, others consider them favorable to the expansion of global trade, or consider them strategic (Osborne, 1995).

It is noted that each player has a completely different hierarchy of preferences, which suggests a lack of consensus.

This analysis is based on incomplete information and the presumption of information disclosure in the course of negotiations. It provides a clarification of how to sequentially reveal positions and possible changes in support models as players make concessions and compromises - concretely by progressively supporting the strategies below in the hierarchy when it is rational to do so. This model, which shows how players respond to each other over time, tries to explain the dynamics of international negotiations in multiplayer games (Edmonds, Hales, 2004).

Multilateral negotiations can often be reduced to bilateral negotiations or a series of bilateral negotiations, but this simplification can not always be done. This is the case with world trade negotiations where there are at least three major players, making it impossible to reduce the conflict to a two-player game (Oprică, 2006).

Players' positions on agriculture are divergent. The issue of market access may, if it is a matter of course, be a means of restructuring players in regional blocks and of negatively influencing the fundamental nature of the game of international trade.

Analysis of the gameplay between players, reflecting both their positions on agriculture and market access, shows that not only their preferences differ but, moreover, one or more players will have to make significant compromises to reach a consensus. 
Within the bargaining model, player-held information on the preferences of others was limited, revealing itself during the rounds of negotiations. information, as well as finding new information along the way, are two absolutely plausible assumptions in the negotiations.

\section{Conclusions}

We believe that gaming theory could be a tool to streamline negotiations (in terms of time spent deploying them, resolving conflict situations, selecting the most appropriate stakeholder, comparing the results with a certain determined or determinable optimum). The main limitation of the applicability of game theory to negotiation remains the impossibility of representing models that apply directly to particular situations, but can be a means of guiding the negotiation process and delimiting the factors and variables that influence business decision-making.

\section{References}

Albin, C. 2001. Justice and fairness in international negotiation, Cambridge University.

Edmonds, B.; Hales, D. 2004. When and why does haggling occur?, Journal of Artificial Societies and Social Simulation.

Fudenberg, D.; Tirole, J. 1992. Game Theory, Massachusetts Institute of Technology.

Gibbons, R. 1996. An Introduction to Applicable Game Theory, Cambridge.

Guasco, M.P. \& Robinson, P.R. 2007. Principles of negotiation, Entrepreneur Magazine.

Imperato, A.; Andrei, A.; Oprescu, G.; Roman, M. Curs în Reglarea cibernetică în sistemul pieței bunurilor și serviciilor, ASE București

Kennedy, G. 2007. Strategic negotiation, Editura Gower Publishing.

Lewicki, R.J.; Saunders, D.M.; Barry, B. 2006. Negotiation, Editura McGraw-Hill.

Morgan, J. 1998. Game Theory Analysis of Bargaining, Conflict, and Negotiation, Princeton Univerity Press.

Oprică, I. 2006. Teoria jocurilor:Conflict sau cooperare?, Revista Știinţa şi tehnica, Nr. 6, Iunie.

Osborne, M. 1995. Introduction to game theory, ed. Edinburgh, p 47

Poundstone, W. 1992. Prisoner's Dilemma: John von Neumann, Game Theory and the Puzzle of the Bomb, Anchor Books, New York.

Spoelstra, M.; Piennar, W. 2008. Negotiation: Theory, Strategies and Skills, Second Edition, Creda Communications.

Ury, W. 1994. Dincolo de refuz. Ghid al negocierilor cu parteneri dificili, Editura de Vest, Timisoara.

von Neumann, J.; Morgenstern, O. 1994. The Theory of Games and Economic Behaviour, Princeton University Press. 